\title{
Preparation and Immobilization of Ti-based Oxides by Detonation Method
}

\author{
YAN Hong-Hao, ZHAO Tie-Jun, LI Xiao-Jie, WU Lin-Song \\ (State Key Laboratory of Structural Analysis for Industrial Equipment, Dalian University of Technology, Dalian 116024, China)
}

\begin{abstract}
Ti-doped gel, prepared by hydrolysis of tetrabutyl titanate and ammonium nitrate solution, was mixed with hexogen to make mix explosive. The mix explosive was detonated in a closed kettle in cylindrical charge with presence of aluminum plate, and then Ti-based oxides were fabricated. The samples were characterized by XRD, TEM, EDX, and SEM. The results showed that samples contained $\mathrm{FeTiO}_{3}$, a few of rutile, anatase, and $\mathrm{Al}_{2} \mathrm{O}_{3}$. The Ti-based oxides particles were spherical in micrometer level scale. Ti-based oxides were successfully immobilized on an aluminum plate driven by Ti-contained detonation wave, and the size of particles on the plate was $10 \mu \mathrm{m}$. The present results suggest that the detonation method provides an easy way to prepare Ti-based oxides and fabricate particle-plate structure for recycling materials synchronously.
\end{abstract}

Key words: detonation method; Ti-based oxides; particle-plate structure; immobilization

Titanium dioxide is a kind of semiconductive materials and has a great potential application in sewage purification, dye-sensitized solar cells, photocatalytic hydrogen generation, and so on ${ }^{[1-4]}$. Ti-based oxides are developed upon titanium dioxide, and contain other metal element (such as $\mathrm{Al}$, $\mathrm{Fe}, \mathrm{Na}, \mathrm{Mg}$ ) with special performances. For example, aluminum titanate $\left(\mathrm{Al}_{2} \mathrm{TiO}_{5}\right)$ is a kind of ceramic material with low thermal expansion properties, high thermal shock resistance and high melting point, which can be applied as thermal barrier in automotive engines ${ }^{[5-9]}$. $\mathrm{FeTiO}_{3}$, a wide band gap $(2.54 \mathrm{eV})$ antiferromagnetic material, is another Ti-based oxide, which has potential applications to absorption, photocatalysts and electronic devices ${ }^{[10-12]} \cdot \mathrm{Al}_{2} \mathrm{TiO}_{5}$ and $\mathrm{FeTiO}_{3}$ are two typical semiconductors ceramic materials, which have a broad potential application, therefore, many researchers pay much attention to the fabrication of these materials. Usually, $\mathrm{Al}_{2} \mathrm{TiO}_{5}$ and $\mathrm{FeTiO}_{3}$ can be prepared by Sol-Gel method ${ }^{[10]}$, sintering ${ }^{[6-7]}$, and hydrothermal ${ }^{[12]}$. However, most of these methods are limit by time-consuming, energy-intensive and low-yield. So, the synthesis technology of Ti-based oxides $\left(\mathrm{Al}_{2} \mathrm{TiO}_{5}\right.$ and $\mathrm{FeTiO}_{3}$ ) still needs to make some breakthrough.

Self propagating high-temperature synthesis (SHS), also called combustion method, is a developed method to prepare materials. The reactant was ignited to produce combustion wave, which will spread to unreacted part until the reaction is completed ${ }^{[13-15]}$. While, as a developing method to prepare materials, the explosive is used as energy source to decompose precursor and synthesize new materials in detonation method ${ }^{[16-17]}$. It is obviously that the high temperature, high pressure and high velocity of detonation wave will occur in explosion of explosive ${ }^{[18]}$. The significant distinction between detonation method and SHS is detonation wave, which has much higher spread velocity than combustion wave. So high purity, high crystalline phase would be fabricated by detonation method, such as carbon-encapsulated metal nanoparticles ${ }^{[16,19-20]}$, metal oxides ${ }^{[21-23]}$, diamond ${ }^{[24-25]}$. Easy to operate, high energy output and short reaction time are unique characters of detonation method ${ }^{[26]}$. Nevertheless, the consistency of precursor and explosive should be taken into consideration before experiment.

Many inorganic materials are fabricated by detonation method, however, there are few reports on detonation synthesis of Ti-based oxides. In present paper, a novel method of preparing Ti-based oxides was studied, which was based on Sol-Gel method and detonation method, in order to diminish time-cost. Mostly, the powders, prepared by detonation method, are dispersed in liquid for degradation experiment ${ }^{[22]}$, friction-wear test ${ }^{[20]}$, and so on. However, it is a waste of powders, and the materials could not be recycled. In some case, the powders needs be reused for many times, so the recycling technology needs to be studied. Similar to explosive welding technology ${ }^{[27-28]}$ which has been used to weld a multi-metallic sheet with a special colliding velocity of fly sheet, a particle-plate structure could be produced with a colliding velocity of the nano particle to base sheet, and nano materials could 
be reused. In this article, the immobilization of nanometer materials, like particle-plate structure, was studied during detonation synthesis of Ti-based oxides powders.

\section{Materials and experiment}

Experimental materials: tetrabutyl titanate (AP, Tianjin Yuanli Chemical Co., Ltd), absolute ethyl alcohol (AP, Sinopharm Chemical Reagent Co., Ltd), acetic acid (AP, Tianjin Kermel Chemical Reagent Co., Ltd), ammonium nitrate (AP, Tianjin Fuchen Chemical Reagent Plant), hexogen (RDX).

\subsection{Synthesis of Ti-doped gel}

As seen in Fig. 1, $10 \mathrm{~mL}$ absolute ethyl alcohol and $10 \mathrm{~mL}$ acetic acid were mixed uniformly in a beaker with stirring on a magnetic stirrer. $25 \mathrm{~mL}$ tetrabutyl titanate was dropped into the mix solution and stirred continuously. Then, tetrabutyl titanate solution was hydrolyzed by preconfigured saturated ammonium nitrate solution added drop by drop, at the same time, the stirrer was rapidly stirred until tetrabutyl titanate solution completely formed a Ti-doped gel.

The hydrolysis reaction of tetrabutyl titanate is quite complicated ${ }^{[29-30]}$, and the mainly reaction equation could be written as follow:

$$
\mathrm{Ti}\left(\mathrm{OC}_{4} \mathrm{H}_{9}\right)_{4}+4 \mathrm{H}_{2} \mathrm{O}=\mathrm{Ti}(\mathrm{OH})_{4}+4 \mathrm{C}_{4} \mathrm{H}_{9} \mathrm{OH}
$$

\subsection{Preparation and characterization of Ti- based oxides}

The preparation of Ti-based oxides was as shown in Fig. 1. After aging and drying, the Ti-doped gel and RDX were mixed with mass ratio of $1.5: 1$ and $1: 1$, respectively. $100 \mathrm{~g}$ of mix explosive was packed in cylindrical charge and detonated in a closed detonation reaction kettle (Fig. 2, inner diameter is $750 \mathrm{~mm}$, volume is $225 \mathrm{~L})^{[20]}$. After $10 \mathrm{~min}$, the detonation products were collected and

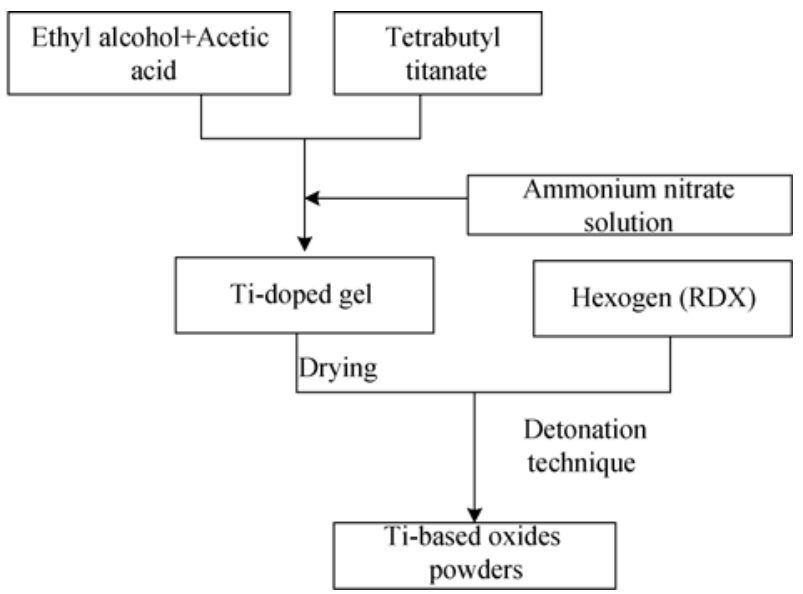

Fig. 1 Schematic diagram of preparing Ti-doped gel precursor and Ti-based oxides powders

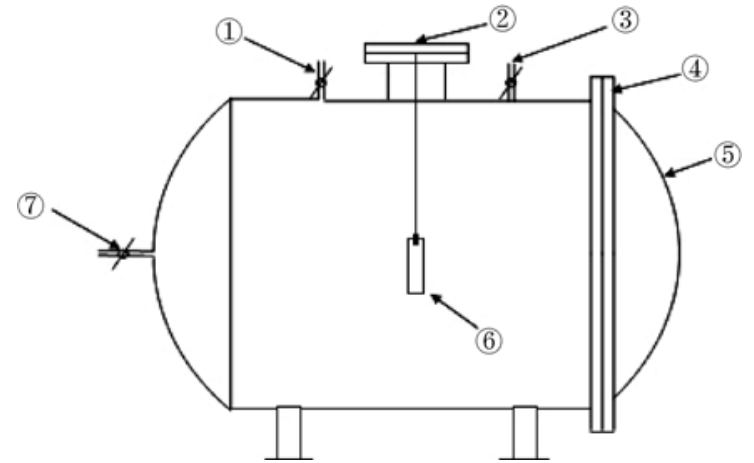

Fig. 2 Schematic of detonation reaction kettle

(1)Extract opening; (2) Top flange; (3) Connection of vacuum gauge;

(4) Large flange; (5) Vessel cover; (6) mix explosive; (7) Air intake

marked as S1 and S2, respectively. During the preparation of sample S2, an aluminum plate (specification was $150 \mathrm{~mm} \times$ $500 \mathrm{~mm} \times 0.6 \mathrm{~mm}$ ) was placed under the cylindrical charge on the inner wall of reaction kettle to study the immobilization of particles. The detail information about detonation synthesis of nanomaterials can be found in our achievements $^{[20,22,31-32]}$.

X-ray powder diffractometer (D/MAX 2400, Japan Rigaku Corporation, $\mathrm{Cu}$ target, $\mathrm{K} \alpha, 40 \mathrm{kV}, 30 \mathrm{~A}$ ) was used to analyze the phase of samples. A glass perform was made by pressing some sample powders on a glass groove, and tested in a measurement range of $10^{\circ}-85^{\circ}$ and at a speed of $8^{\circ} / \mathrm{min}$. Microstructure and element constitution of samples were analyzed by transmission electron microscope (Tecnai F30, U.S FEI corporation) and EDX component. Some powders were added in alcohol, and the solution was vibrated by ultrasonic wave for $15 \mathrm{~min}$. Then, taking a drop of solution dropped into a micro-grid and tested after drying in the air. The morphology of sample powders and particle-plate structure was characterized by scanning electron microscope (FEI Quanta 200 and JSM-5600LV). The elemental composition of particle-plate structure and morphological feature of S2 were assessed by JSM-5600LV.

\section{Results and analysis}

\subsection{XRD analysis}

XRD patterns of samples is shown in Fig. 3. Sample S1 and $\mathrm{S} 2$ are consisted of four phases, which are anatase, rutile, $\mathrm{FeTiO}_{3}$ and $\mathrm{Al}_{2} \mathrm{O}_{3}$. The XRD peaks at $2 \theta=25.68^{\circ}$ can be indexed to (101) crystal face of anatase. The reflection peak at $2 \theta=27.05^{\circ}, 43.41^{\circ}, 53.46^{\circ}, 55.78^{\circ}, 67.88^{\circ}$ and $68.50^{\circ}$ could be indexed to rutile, however the peak of rutile shifts a little to low degree, it's perhaps caused by the sample preparation during XRD test. The peak at $2 \theta=32.62^{\circ}, 46.57^{\circ}$ are from the (112), (202) crystal face of $\mathrm{FeTiO}_{3}$ and $\mathrm{Al}_{2} \mathrm{O}_{3}$, respectively. From Fig. 3, we can find 


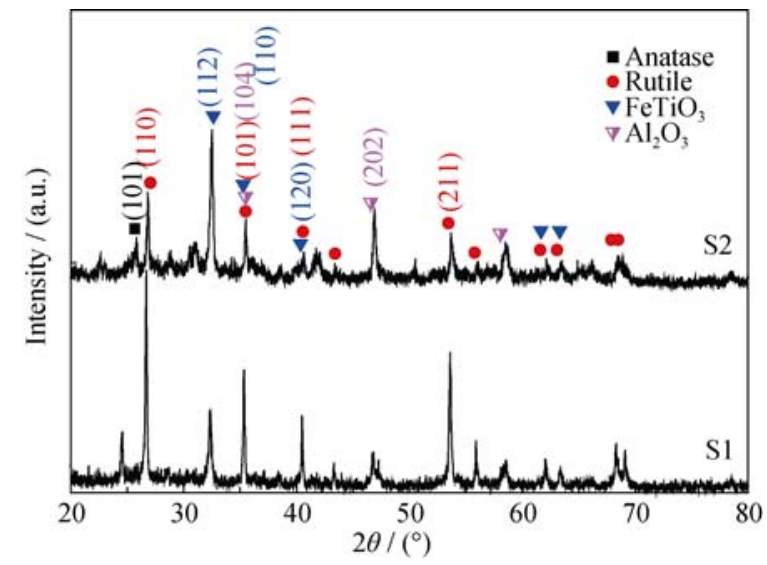

Fig. 3 XRD patterns of samples

The mass ratios of Ti-doped gel and RDX in S1 and S2 are $1.5: 1,1:$ 1 , respectively

that the peaks at $35.2^{\circ}$ and $40.4^{\circ}$ are from multiphase of rutle, $\mathrm{FeTiO}_{3}$ and $\mathrm{Al}_{2} \mathrm{O}_{3}$, and the crystal faces of three phases are marked on Fig. 3. The rest low intensity peaks are caused by impurity in samples. In sample S1 preparation process, there was a small quantity of aluminum fused on inner wall of the reaction kettle, which was unable to clear it away. So after detonating by detonator (iron), the high- temperature Ti-contained gas stream reacted with aluminum, detonator scraps and oxygen, thus generating Ti- based metallic oxide, aluminum oxide, and iron oxide.

\subsection{EDX analysis}

In order to further determine elements composition of samples, EDX analysis was used, and the results are shown in Fig. 4. It can be seen from the Fig. 4 that both S1 and S2 contain a large quantity of $\mathrm{C}, \mathrm{Cu}, \mathrm{Ti}$, and $\mathrm{O}$ elements as well as a small quantity of $\mathrm{Fe}, \mathrm{Al}$ elements. $\mathrm{C}$ and $\mathrm{Cu}$ elements came from the carrier used in characterization. EDX analysis could explain the Ti-based metallic oxides appearing in XRD characterization results very well. Combined with XRD analysis results, the samples consisted of titanium dioxide and Ti-based metallic oxides.

\subsection{TEM characterization}

Morphological features of samples were characterized by TEM as shown in Fig. 5. It can be seen from the images that the samples were spherical or torispherical, and the particle size was at the micrometer level of approximately $100 \mathrm{~nm}$. It was found that the particle size was little enlarged with the proportion of RDX increased by comparing Fig. 5(a-1) and 5(b-1).

\subsection{Characterization of particle-plate structure}

It can be seen a significant deformation of aluminum plate, which caused by shock wave in detonation process as shown in Fig. 6(a). A piece of rectangular aluminum plate was tailored from the aluminum plate, and characterized by SEM after ultrasonic cleaning.
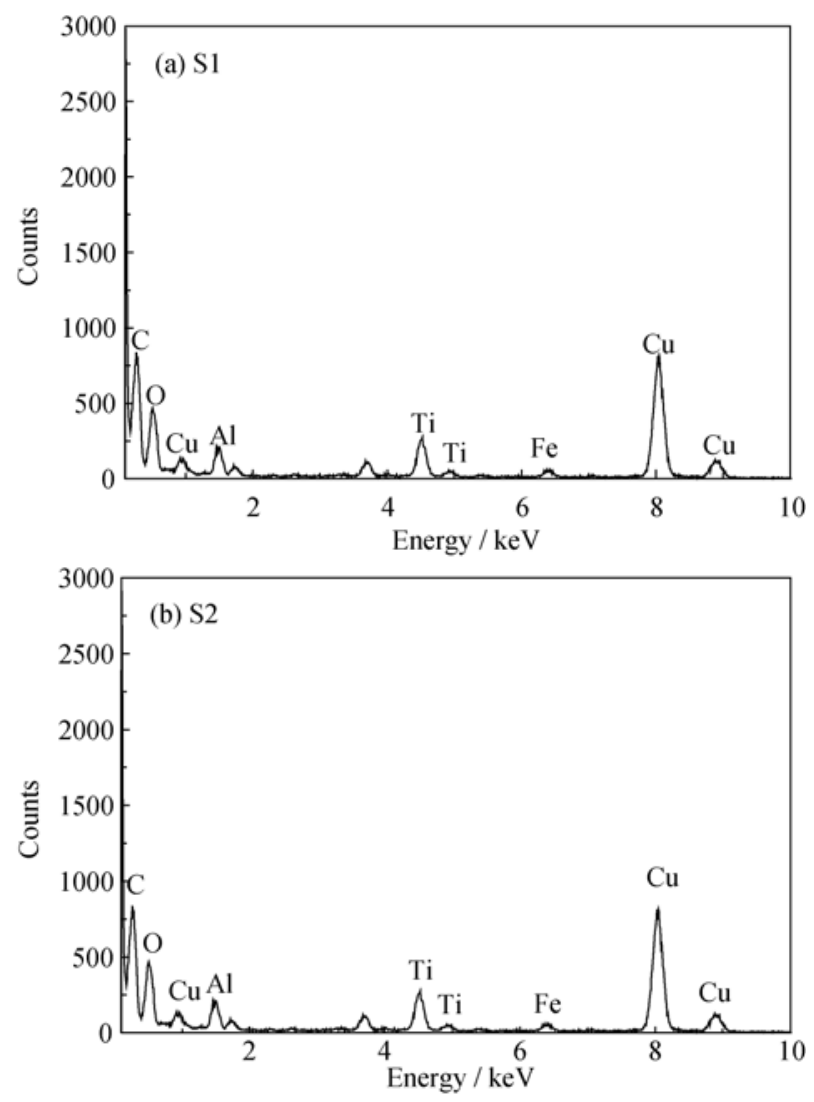

Fig. 4 EDX pattern of samples

The mass ratios of Ti-doped gel and RDX in S1 and S2 are $1.5: 1,1: 1$, respectively
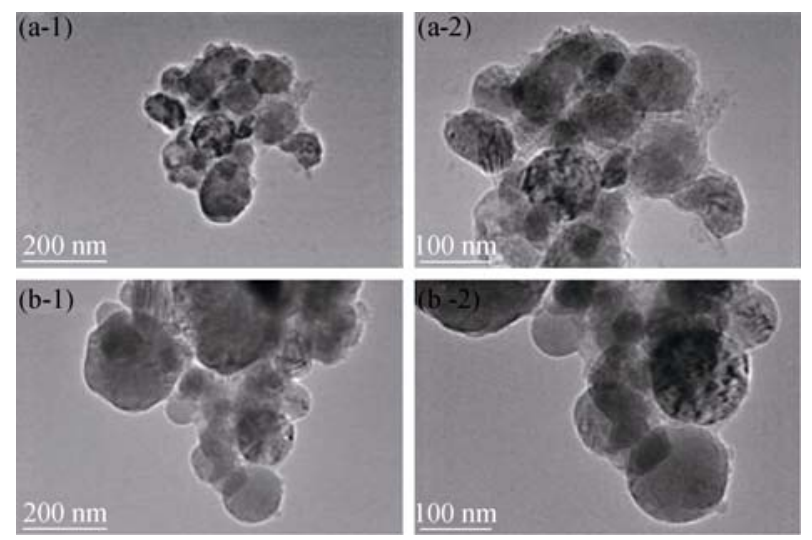

Fig. 5 TEM images of samples (a) and (b) are from S1 and S2, respectively

Fig. 7 shows the SEM pictures of sample S2 Ti-based oxides particles and the immobilization of Ti-based oxides on aluminum plate. It can be seen from Fig. 7 (a) that Ti-based oxides particles present spherical distribution. Most of them are smaller than $5 \mu \mathrm{m}$, except for some larger than $10 \mu \mathrm{m}$. Fig. 7 (b) shows the distribution status of Ti-based oxides particles on aluminum plate surface. It can be clearly seen from Fig. 7 (b) that many spherical particles are uniformly immobilized on aluminum plate surface, and some parts of the plate were corroded by high-temperature 


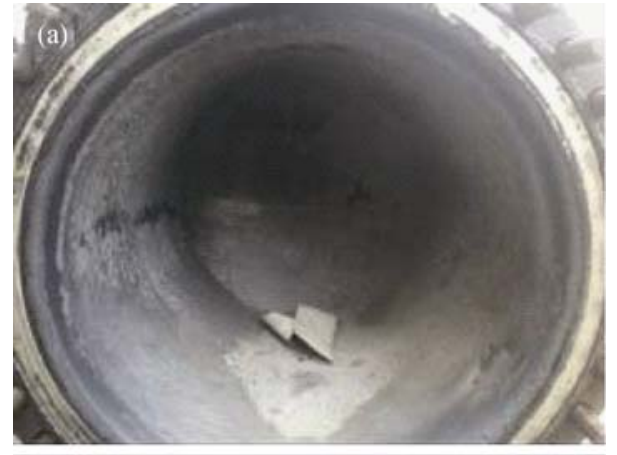

(b)

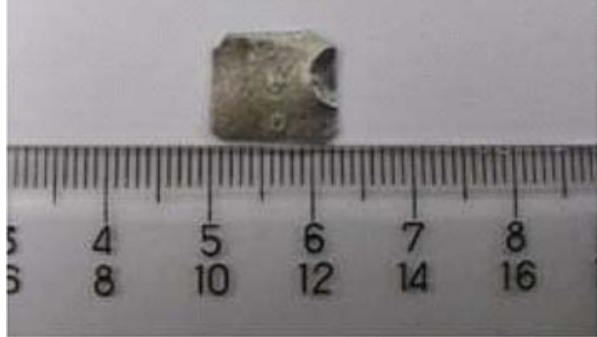

Fig. 6 Aluminum plate morphologies after denotation reaction in preparation of $\mathrm{S} 2$

(a) Aluminum plate after detonation reaction in reaction kettle; (b) $\mathrm{A}$ piece of aluminum plate for SEM characterization
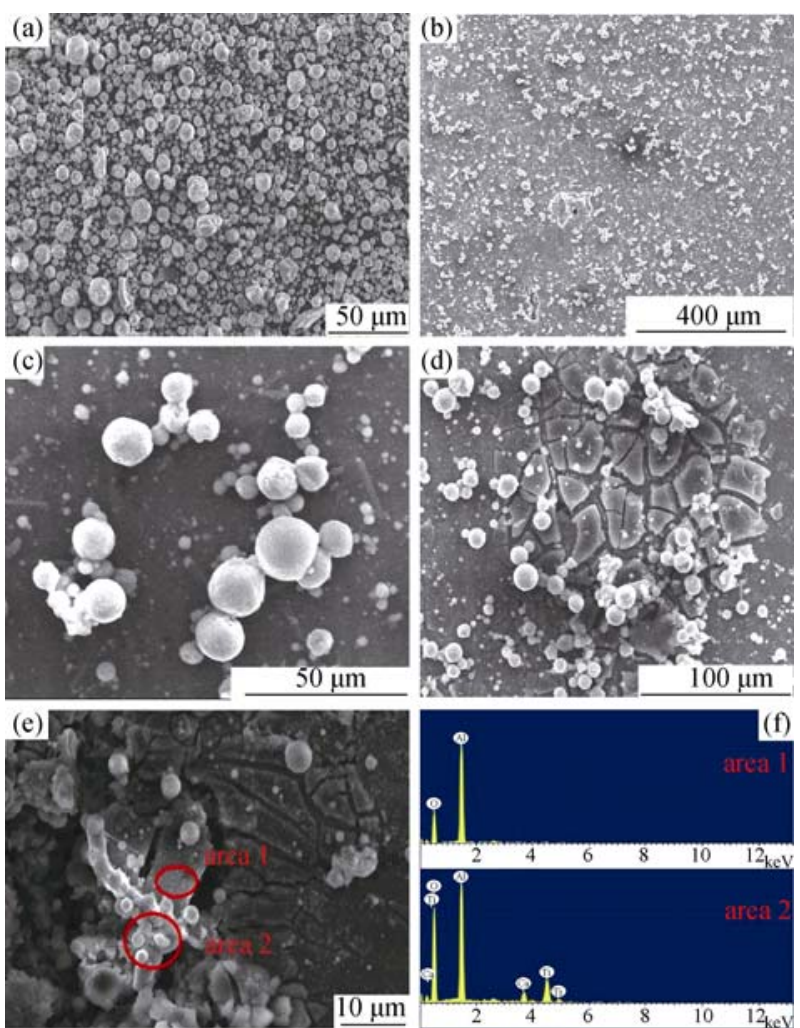

Fig. 7 SEM images of $\mathrm{TiO}_{2}$ particles and particle-plate materials from sample $\mathrm{S} 2$

(a): $\mathrm{TiO}_{2}$ particles; (b): Overall morphology of particle-plate; (c) and (d): Enlarged picture of local areas of particle-plate structure; (e): Morphology of corroded area on aluminum plate surface; (f): Element composition of area selected in Fig. (e) impact during detonation process, causing certain damage. Undamaged part and corroded part of the aluminum plate were characterized in detail, as shown in Fig. 7(c) and 7(d). From Fig. 7(c), it can be found that spherical particles are immobilized on aluminum plate surface forming a particle-plate structure. The particle size is approximately $10 \mu \mathrm{m}$, and many smaller particles also can be seen on the plate. In corroded area (Fig. 7(d)), many particles cluster can be seen, which caused by collision of spherical particles in detonation reaction, and the small particles in the gaps of corroded area also are obviously. The size of Ti-based oxides particles, immobilized on aluminum plate, are similar with the powders from that of sample S2.

Analysis of elemental composition of particle-plate structure from corroded area is shown in Fig. 7(e) and 7(f). It can be seen from Fig. 7(e) and (d) that the aluminum plate surface has already been oxidized as aluminum oxide under high-temperature impact. Spherical particles in area 2, which is near area 1 , are mainly consisted of $\mathrm{Ti}, \mathrm{O}$ and $\mathrm{Al}$ elements as well as a small quantity of $\mathrm{Ca}$ element. The gap of corroded area in Fig. 7(e) also contains Ti element through characterization, indicating that the aluminum plate was reacted with high-temperature Ti-contained shock wave and oxygen in kettle to form Ti-based oxides and particle-plate structure. Hence, it is feasible to use an aluminum plate surface sedimentation/shock to form particle-plate component. In addition, compared with the inner wall of the steel reaction kettle, it is easier for particles to realize immobilization on the aluminum plate, where adhering products on the inner wall of the reaction kettle can be easily removed, whereas particles on the aluminum plate can still maintain the aluminum plate surface after ultrasonic oscillation treatment.

\section{Conclusion}

In present paper, Ti-based oxides were prepared by detonation method with presence of Ti-doped gel and aluminum plate. Meanwhile, a particle-plate structure for recycling powders was manufactured during detonation synthesis of Ti-based oxides particles. X-ray diffractometer, TEM, and SEM were used to assess the samples. Results found that the powders were consisted of $\mathrm{Al}_{2} \mathrm{TiO}_{5}$, $\mathrm{FeTiO}_{3}$, and a small amount of rutile, anatase $\mathrm{TiO}_{2}$, and $\mathrm{Al}_{2} \mathrm{O}_{3}$. The particles were spherical shape with a micrometer level scale. Ti-based oxides could be immobilized on aluminum plate surface as driven by detonation waves, and the size of particles on the aluminum plate was about $10 \mu \mathrm{m}$, which was larger than the naturally collected powders. It should be note that Ti-based oxides particles 
could be prepared and immobilized on aluminum plate at the same time by detonation method, which is important for the application of detonation method.

\section{References:}

[1] LI L D, YAN J Q, WANG T, et al. Sub-10 nm rutile titanium dioxide nanoparticles for efficient visible-light-driven photocatalytic hydrogen production. Nature Communications, 2015, DOI: 10.1038/ncomms6881.

[2] JIANG X, QIN X, GONG M, et al. Improvement of surfaceenhanced Raman scattering properties of $\mathrm{TiO}_{2}$ nanoparticles by metal $\mathrm{Ni}$ doping. Chemical Journal of Chinese Universities-Chinese, 2014, 35(3): 488-492.

[3] XIAO Q, SI Z, ZHANG J, et al. Photoinduced hydroxyl radical and photocatalytic activity of samarium-doped $\mathrm{TiO}_{2}$ nanocrystalline. Journal of Hazardous Materials, 2008, 150(1): 62-67.

[4] SU X, WU Q L, ZHAN X, et al. Advanced titania nanostructures and composites for lithium ion battery. Journal of Materials Science, 2012, 47(6): 2519-2534.

[5] INNOCENZI P, MARTUCCI A, ARMELAO L, et al. Sol-Gel synthesis of beta- $\mathrm{Al}_{2} \mathrm{TiO}_{5}$ thin films at low temperature. Chemistry of Materials, 2000, 12(2): 517-524.

[6] NAGANO M, NAGASHIMA S, MAEDA H, et al. Sintering behavior of $\mathrm{Al}_{2} \mathrm{TiO}_{5}$ base ceramics and their thermal properties. $\mathrm{Ce}$ ramics International, 1999, 25(8): 681-687.

[7] CUI H Z, XU G G, GE C L, et al. Synthesis of porous $\mathrm{Al}_{2} \mathrm{TiO}_{5}$ ceramic by reaction sintering method. Journal of the Ceramic Society of Japan, 2012, 120(1406): 413-416.

[8] SKALA R D, LI D, LOW I M. Diffraction, structure and phase stability studies on aluminium titanate. Journal of the European Ceramic Society, 2009, 29(1): 67-75.

[9] BRUNO G, EFREMOV A, WHEATON B, et al. Micro- and macroscopic thermal expansion of stabilized aluminum titanate. Journal of the European Ceramic Society, 2010, 30(12): 2555-2562.

[10] MONA J, KALE S N, GAIKWAD A B, et al. Chemical methods to synthesize $\mathrm{FeTiO}_{3}$ powders. Materials Letters, 2006, 60(11): $1425-1427$.

[11] TRUONG Q D, LIU J Y, CHUNG C C, et al. Photocatalytic reduction of $\mathrm{CO}_{2}$ on $\mathrm{FeTiO}_{3} / \mathrm{TiO}_{2}$ photocatalyst. Catalysis Communications, 2012, 19: 85-89.

[12] ZHANG X B, LI T T, GONG Z Q, et al. Shape controlled $\mathrm{FeTiO}_{3}$ nanostructures: crystal facet and photocatalytic property. Journal of Alloys and Compounds, 2015, 653: 619-623.

[13] ZHU CH C, ZHANG X H, HE X D. Self-propagating hightemperature synthesis of $\mathrm{TiC}-\mathrm{TiB}_{2} / \mathrm{Cu}$ ceramic-matrix composite.
Journal of Inorganic Materials, 2003(4): 872-878.

[14] ZHANG T A, DOU ZH H. Growth mechanism of $\mathrm{TiB}_{2}$ powder prepared by SHS-metallurgy. Journal of Inorganic Materials, 2006(3): 583-590.

[15] LIANG L P, LIU Y C, WANG J H. Development prospect of self-propagating high temperature synthesis. Applied Chemical Industry, 2006(9): 716-718.

[16] LU Y, ZHU Z P, LIU Z Y. Carbon-encapsulated Fe nanoparticles from detonation-induced pyrolysis of ferrocene. Carbon, 2005, 43(2): 369-374.

[17] LUO N, LI X J, LIU K X, et al. Preparation of carbon-coated copper nanoparticles by detonation decomposition of copper ion doped sol-gel explosive precursors. Journal of Nanoparticle Research, 2013, 15(5): 1614-1-9.

[18] LI X J, QU Y D, YAN H H, et al. Research progress on nanosized materials synthesized by detonation dethod. Rare Metal Materials and Engineering, 2007(12): 2069-2074.

[19] LUO N, LI X J, WANG X H, et al. Synthesis of carbon-encapsulated metal nanoparticles by a detonation method. Combustion Explosion and Shock Waves, 2010, 46(5): 609-613.

[20] YAN H H, ZHAO T J, LI X J, et al. Detonation synthesis and friction-wear test of carbon-encapsulated copper nanoparticles. Journal of Inorganic and Organometallic Polymers and Materials, 2015, 25(6): 1569-1575.

[21] QU Y D, KONG X Q, LI X J, et al. Effect of thermal treatment on the structural phase transformation of the detonation-prepared $\mathrm{TiO}_{2}$ mixed crystal nanoparticles. Acta Physica Sinica, 2014, 63(3): 037301-1-72.

[22] YAN H H, ZHAO T J, LI X J, et al. Synthesis of Cu-doped nano- $\mathrm{TiO}_{2}$ by detonation method. Ceramics International, 2015, 41(10): 14204-14211.

[23] YAN H H, WU L S, LI X J, et al. Detonation synthesis of $\mathrm{SnO}_{2}$ nanoparticles in gas phase. Rare Metal Materials and Engineering, 2013, 42(7): 1325-1327.

[24] DOLMATOV V Y. Detonation synthesis ultradispersed diamonds: properties and applications. Uspekhi Khimii, 2001, 70(7): 687-708.

[25] OLEINIK G S, BOCHECHKA A A. On the mechanism of forming nanosized particles of diamond detonation synthesized from explosive decomposition products. Journal of Superhard Materials, 2008, 30(3): 143-162.

[26] YAN H, ZHAO T, LI X, et al. Hydrogen and air detonation (deflagration) synthesis of carbon-encapsulated iron nanoparticles. Combustion Explosion and Shock Waves, 2015, 51(4): 495-501.

[27] DURGUTLU A, GULENC B, FINDIK F. Examination of cop- 
per/stainless steel joints formed by explosive welding. Materials \& Design, 2005, 26(6): 497-507.

[28] LOUREIRO A, MENDES R, RIBEIRO J B, et al. Effect of explosive mixture on quality of explosive welds of copper to aluminium. Materials \& Design, 2016, 95: 256-267.

[29] SUGIMOTO T, ZHOU X. Synthesis of uniform anatase $\mathrm{TiO}_{2}$ nanoparticles by the Sol-Gel method 2. Adsorption of $\mathrm{OH}^{-}$ions to $\mathrm{Ti}(\mathrm{OH})_{4}$ gel and $\mathrm{TiO}_{2}$ particles. J. Colloid Interface Sci., 2002, 252(2): 347-353.

[30] SUGIMOTO T, ZHOU X, MURAMATSU A. Synthesis of uniform anatase $\mathrm{TiO}_{2}$ nanoparticles by Gel-Sol method. 1. Solution chemistry of $\mathrm{Ti}(\mathrm{OH})(4-\mathrm{n})+(\mathrm{n})$ complexes. J. Colloid Interface Sci., 2002, 252(2): 339-346.

[31] LUO N, LI X J, WANG X H, et al. Synthesis and characterization of carbon-encapsulated iron/iron carbide nanoparticles by a detonation method. Carbon, 2010, 48(13): 3858-3863.

[32] SUN G L, LI X J, WANG Q Q, et al. Synthesis of carbon-coated iron nanoparticles by detonation technique. Materials Research Bulletin, 2010, 45(5): 519-522.

\title{
爆轰法制备与固载钛基氧化物的研究
}

\author{
间鸿浩，赵铁军，李晓杰，吴林松 \\ (大连理工大学 工业装备结构分析国家重点实验室, 大连 116024)
}

摘 要: 利用钛酸丁酯与硝酸铵溶液制备的含钛凝胶跟黑索金混合后获得混合炸药, 然后在密闭的爆轰反应釜内引爆 柱状混合炸药，同时将一铝板放置于药柱正下方研究爆轰产物的固载问题。收集到的样品用 $\mathrm{X}$ 射线衍射仪、透射电 镜以及扫描电镜进行了表征, 发现样品中含有 $\mathrm{FeTiO}_{3}$, 少量的金红石、锐钣矿及 $\mathrm{Al}_{2} \mathrm{O}_{3}$ 。钛基氧化物颗粒呈球形, 尺 寸大小在微米级别。从扫描电镜分析, 钛基氧化物颗粒被成功地固载于铝板之上, 颗粒约 $10 \mu \mathrm{m}$ 。爆轰法能够很方便 地制备钛基氧化物及制备颗粒一板结构材料。

关 键 词: 爆轰法; 钛基氧化物; 颗粒一板结构; 固载

中图分类号: $\mathrm{O} 389$

文献标识码: A 